\title{
THE EARLY WARNING SYSTEM IN CRIMINAL TAX INVESTIGATIONS
}

Under indictment for failure to file income tax returns, ${ }^{1}$ the defendant in United States $\%$. Dickerson ${ }^{2}$ moved to suppress as evidence all documents and oral statements voluntarily given by him to agents of the United States Internal Revenue Service (IRS) subsequent to the initiation of a criminal tax investigation. Basing his motion on the admitted failure of the IRS agents to advise him of his constitutional rights, the defendant alleged violations of the fourth and fifth amendments. The Court of Appeals for the Seventh Circuit affirmed the district court's decision ${ }^{3}$ to grant defendant's motion to suppress. ${ }^{4}$ To insure voluntary waiver of constitutional rights, said the court, the warnings of Miranda $v$. Arizona ${ }^{5}$ must be given to a taxpayer under investigation at the first contact of IRS agents with the taxpayer after a civil audit has been transferred to the Intelligence Division of the IRS for criminal investigation. ${ }^{6}$

This Comment will demonstrate that the Seventh Circuit in Dickerson, while avoiding the mistakes made by other circuits in applying Miranda to criminal tax investigations, misconstrued Miranda nonetheless. Second, the Comment will point out an alternative approach providing substantially similar protection of the taxpayer's fifth amendment rights.

\section{Escobedo AND Miranda}

To analyze the Dickerson decision requiring IRS special agents to give the Miranda warnings to taxpayers under criminal investigation, an examination of the facts and principles of Miranda and its predecessor, Escobedo v. Illinois, ${ }^{7}$ is necessary. ${ }^{8}$

In Escobedo, the petitioner was arrested on suspicion of murder and taken to police headquarters for interrogation. Petitioner's attorney arrived shortly thereafter. The police refused repeated requests by both the petitioner and his attorney for an opportunity for consultation until Escobedo finally confessed to participating in the murder.

1 INT. REV. CODE of 1954, $\$ 7203$, defines as a misdemeanor the willful failure to file a tax return. Upon conviction, a defendant is subject to imprisonment for not more than 1 year, or a fine of not more than $\$ 10,000$, or both. Id.

2413 F.2d 1111 (7th Cir. 1969).

3 United States v. Dickerson, 291 F. Supp. 633 (N.D. I11. 1968).

418 U.S.C. $\$ 3731$ (Supp. IV, 1969) authorizes the government to appeal from an adverse ruling on a motion to suppress.

5384 U.S. 436 (1966).

6413 F.2d at $1116-17$.

7378 U.S. 478 (1964).

8 The Dickerson investigation began prior to the Supreme Court's decision in Miranda but subsequent to the Court's decision in Escobedo. 413 F.2d at 1113. 
The Supreme Court found that the interrogation was a critical stage of the prosecution-a stage at which counsel was necessary to protect the accused's constitutional rights. ${ }^{9}$ The Court held:

[W] here, as here, the investigation is no longer a general inquiry into an unsolved crime but has begun to focus on a particular suspect, the suspect has been taken into police custody, the police carry out a process of interrogations that lends itself to eliciting incriminating statements, the suspect has requested and been denied an opportunity to consult with his lawyer, and the police have not effectively warned him of his absolute constitutional right to remain silent, the accused has been denied "the Assistance of Counsel" in violation of the Sixth Amendment . . . 10

In Miranda, the Court expanded its narrow Escobedo holding. The Court found that police practices during custodial interrogationofficial overbearing in an intimidating, unfamiliar atmosphere-operated to compel the suspect to abandon his privilege against self-incrimination. ${ }^{11}$ Since custodial interrogation "contains inherently compelling pressures which work to undermine the individual's will to resist and to compel him to speak where he would not otherwise do so freely," 12 the Court required that the police preface any such interrogation with a warning that the suspect

has the right to remain silent, that anything he says can be used against him in a court of law, that he has the right to the presence of an attorney, and that if he cannot afford an attorney one will be appointed for him prior to [the interrogation] .... ${ }^{13}$

Unlike Escobedo, Miranda was based on the fifth amendment. The purpose of the warning is to preserve the suspect's privilege against self-incrimination. ${ }^{14}$ First, it permits him to exercise his privilege intelligently in an atmosphere free from coercive influences; ${ }^{15}$ and second, it makes clear to him "that he is faced with a phase of the adversary

9 See 378 U.S. at 486 . "[A] system of criminal law enforcement which comes to depend on the 'confession' will, in the long run, be less reliable and more subject to abuses than a system which depends upon extrinsic evidence independently secured through skillful investigation." Id. at 488-89 (footnotes omitted). The legal process should not "have to fear that if an accused is permitted to consult with a lawyer, he will become aware of, and exercise, these [fifth and sixth amendment] rights." Id. at 490 (footnote omitted).

10 Id. at $490-91$ (emphasis added).

11384 U.S. at 448-50.

12 Id. at 467.

$13 \mathrm{Id}$. at 479.

14 See id. at $467,478-79$.

$15 I d$. at $468,475$. 
system-that he is not in the presence of persons acting solely in his interest." 16

In Miranda the Court was careful to limit the scope of its holding to "custodial interrogations," that is, to those occasions when the suspect is "in custody at the station or otherwise deprived of his freedom of action in any significant way." 17 Exactly what constitutes custodial interrogation under Miranda, however, has been the subject of much judicial and scholarly examination. ${ }^{18}$ As one commentator has noted in frustration: "[I]n the case of questioning away from the police station, where there is no arrest or detention, it is all but impossible to decide when Miranda-Escobedo rights arise." 19

\section{A. The Criminal Tax Investigation}

A prerequisite to meaningful discussion of Dickerson and its relation to Miranda is a basic understanding of IRS procedures in a criminal tax investigation. Usually, a tax fraud investigation begins as a routine audit of a taxpayer's return by a revenue agent of the IRS Audit Division. ${ }^{20}$ The function of the revenue agent is to examine returns for correct dollars-and-cents liability. If he suspects fraud, and if his superiors concur, then the civil audit is suspended ${ }^{21}$ and the investigation is transferred to a special agent of the IRS Intelligence Division. ${ }^{22}$ A trained criminal investigator, the special agent further examines the nature of the taxpayer's liability. During such examination, the special agent is able to and, when the circumstances warrant, required to gather evidence to support a criminal prosecution. ${ }^{23}$ His

16 Id. at 469.

17 Id. at 444. It is unclear exactly what the Court in Miranda meant by deprivation of freedom of action. See notes $39-46$ infra \& accompanying text.

18 See, e.g., Orozco v. Texas, 394 U.S. 324 (1969); Mathis v. United States, 391 U.S. 1 (1968); United States v. Knight, 395 F.2d 971 (2d Cir. 1968), cert. denied, 395 U.S. 930 (1969); United States v. Gibson, 392 F.2d 373 (4th Cir. 1968) ; Windsor v. United States, 389 F.2d 530 (5th Cir. 1968) ; Kamisar, "Custodial Inferrogation" Within the Meaning of Miranda, in CRIMINAL LAW AND THE Constitution 335, 362-82 (1968) ; Najarian, Miranda v. Arizona: In-Custody Interrogation: An Examination of the New Rules Further Defining the Suspect's Rights, 71 DICK L. Rev. 116 (1966) ; Comment, The Privilege Against Self-Incrimination: The Scope and Application of Miranda, 37 U. Mo. K.C. L. REv. 260, 264-87 (1969).

10 Graham, What is "Custodial Interrogation?": Califormia's Anticipatory Application of Miranda v. Arizona, 14 U.C.L.A.L. REv. 59, 89 (1966).

20 See Andrews, The Right to Connsel in Criminal Tax Investigations Under Escobedo and Miranda: The "Critical Stage", 53 Iowa L. Rev. 1074, 1083 (1968). Tax fraud investigations may also begin without the preliminary civil audit when tips are received from informers. See id.

21 See id. 1084.

22 See Hewitt, The Constitutional Rights of the Taxpayer in a Fraud Investigation, 44 TAxes 660, 661 (1966).

23 See Andrews, supra note 20, at 1084-85. For further discussion of the special agent's functions see Statement of Procedural Rules, 26 C.F.R. $\$ 601.107$ (a) (1955); 33 Fed. Reg. 17,234-36 (1968); 34 Fed. Reg. 1657, 1665 (1969); Duke, Prosecutions For Attempts to Evade Income Tax: Discordant View of a Procedural Hybrid, 76 Y ALE L.J. 1, 34-41 (1966) ; Weiss, Do Taxpayers Have Constitutional Rights?, 46 TAxes 494, 498 (1968); Comment, Fifth Amendment Privilege in Criminal Tax Investigations: Miranda and the Ommibus Crime Act, 42 TEMr. L.Q. 255, 256-58 (1969). 
investigation includes one or more interviews with the taxpayer, during which the taxpayer might provide him with documentary and oral evidence necessary to secure conviction. ${ }^{24}$ The next IRS step is the formal interrogation, which offers the taxpayer an opportunity to present evidence to persuade the IRS not to recommend prosecution, but also permits the IRS to gather additional incriminating evidence. ${ }^{25}$ The taxpayer is not ordinarily taken into custody during either his informal contacts with the special agent or the formal interrogation, because neither flight nor further criminal conduct is anticipated, and the crime itself is nonviolent. ${ }^{26}$ If the Justice Department concurs with IRS recommendations, an indictment is issued.

Prior to the Supreme Court's decisions in Escobedo and Miranda, courts did not consider the opportunities presented to the IRS to elicit incriminating evidence from the taxpayer. Though a taxpayer could invoke his fifth amendment privilege to withhold incriminating oral and documentary testimony during an interrogation by an IRS special agent, ${ }^{27}$ it was well-established that the IRS special agents had no duty to advise a taxpayer of his constitutional rights or to inform him that he was under criminal investigation. ${ }^{28}$ Furthermore, the voluntariness rule applied by the courts provided that if a person accused of a crime volunteered evidence in the absence of fraud, coercion, misrepresentation, or deceit, a conscious waiver of his constitutional rights was not essential to the admissibility of the evidence in a criminal trial. ${ }^{29}$ Although the appearance of the special agent and the setting of the interviews (usually the taxpayer's home or office) would not alert the average taxpayer to the fact that he was undergoing a criminal investigation, ${ }^{30}$ the courts presumed that once a civil investigation

24 As a former special agent of the IRS has noted:

At the outset of an investigation the average taxpayer is only too anxious to cooperate, or give the appearance of cooperating, and gives the Special Agent all of his incriminating records and makes damaging admissions. He usually wants to show he has nothing to hide, so he doesn't invoke his constitutional rights, even if he should happen to know them. Furthermore, he does not know the significance of a Special Agent, believing him just to be another agent there to determine how much he owes, and he wants to incur his goodwill. Of course, until recently the Special Agent would not disabuse him of these impressions and, more often than not, would encourage them. Making a case against an unrepresented taxpayer is frequently like "taking candy from a baby."

H. Mednick, The Taxpayer's "Right to Counsel" in a Criminal Case, Dec. 15, 1969 (unpublished memorandum in Biddle Law Library at the University of Pennsylvania).

25 See Hewitt, supra note 22, at 692.

26 Andrews, supra note 20, at 1085 n.56.

27 See Gilbert v. California, 388 U.S. 263, 266-67 (1967) ; Shapiro v. United States, 335 U.S. 1, 26-27 (1948).

28 See, e.g., United States v. Sclafani, 265 F.2d 408, 414 (2d Cir.), cert. denied, 360 U.S. 918 (1959) ; Turner v. United States, 222 F.2d 926, 931 (4th Cir.), cert. denied, 350 U.S. 831 (1955); United States v. Burdick, 214 F.2d 768, 773 (3d Cir. 1954), cert. denied, 348 U.S. 905 (1955).

29 See Hewitt, supra note 22, at 662-64.

30 See id. 690; Ludlam, Tax Frand Investigations: A Plea for Constitutional Procedures, 43 A.B.A.J. 1009, 1010 (1957). 
began, the taxpayer knew that it might become a criminal investigation..$^{31}$

\section{B. Application of Miranda in Tax Cases}

The Supreme Court's decisions in Escobedo and Miranda forced the lower federal courts and the IRS to reconsider the implications of the voluntariness rule in criminal tax investigations. Dickerson was the first circuit court opinion holding that the Miranda warnings are required; but like Dickerson, the prior courts of appeals cases failed to analyze fully the applicability of Miranda to tax cases.

The Miranda Court found "custodial interrogation"-defined as interrogation after a suspect is "taken into custody or otherwise deprived of his freedom of action in any significant way" 32 - so fraught with inherent psychological pressures that " $[t]$ he potentiality for compulsion is forcefully apparent." "33 "[O]vert physical coercion or patent psychological ploys" 34 need not be found in order to exclude a confession: "the compulsion inherent in custodial surroundings" ${ }^{35}$ is sufficient to require warnings to insure that a "statement obtained from the defendant can truly be the product of his free choice." 36

Because IRS investigations usually take place in the taxpayer's own home or office, ${ }^{37}$ the station house interrogation part of the Miranda holding is inapplicable to taxpayer interrogations. ${ }^{38}$ But even if the suspect is not in formal custody, the Miranda warnings may be required if he is "otherwise deprived of his freedom of action in any significant way." A court must investigate the meaning of this phrase before it can determine that warnings are or are not required.

31 See, e.g., United States v. Sclafani, 265 F.2d 408 (2d Cir.), cert. denied, 360 U.S. 918 (1959), in which it was stated that:

A "routine" tax investigation openly commenced as such is devoid of stealth or deceit because the ordinary taxpayer surely knows that there is inherent in it a warning that the government's agents will pursue evidence of misreporting without regard to the shadowy line between avoidance and evasion, mistake and willful omission.

Id. at $414-15$.

32384 U.S. at 444 (footnotes omitted).

33 Id. at 457 . That the IRS agent is not a police officer is not important when considering whether Miranda controls. In Mathis v. United States, 391 U.S. 1 (1968), the warnings were required during a custodial investigation even though the investigator was an IRS regular agent.

34384 U.S. at 457. In Mathis v. United States, 391 U.S. 1 (1968), the Court, upon finding a custodial interrogation, made no attempt to determine whether in fact there had been any evidence that the defendant was compelled to confess. See 391 U.S. at 7-8 (White, J., dissenting).

35384 U.S. at 458.

$36 I d$.

37 See note 26 supra \& accompanying text.

38 Should the IRS interview a man in custody, however, the required warnings must be given. See Mathis v. United States, 391 U.S. 1 (1968) ; cf. Orozco v. Texas, 394 U.S. 324, 327 (1969) (Harlan, J., concurring). For a discussion of these cases see text accompanying notes $48-52$ infra. 
The significance the Court intended this phrase to carry is unclear. Commentators have suggested two possible readings: that the Court was concerned with the situation of a suspect in any form of physical custody ${ }^{39}$ outside the station house setting, or that the Court was concerned with the psychological setting of any investigation. ${ }^{40}$ Adherents of the former reading point to the two different ways the phrase is used in the Miranda opinion: ${ }^{41}$

police interrogation while in custody at the [police] station or otherwise deprived of his freedom of action in any significant way, ${ }^{42}$

and

taken into custody or otherwise deprived of his freedom of action in any significant way. ${ }^{43}$

From the difference in wording, and from the constant use of "custody" rather than "arrest," commentators have suggested that the Court was attempting to protect citizens not in formal custody at the station house but nevertheless physically restrained by the police.

[T] he Court understandably (albeit gingerly and uncertainly) sought to protect its flanks. If "custodial interrogation" were limited to questioning in a police station or to questioning that occurs after a formal arrest, "the police would need only to delay formal arrest or physical transfer of an accused to the station house in order to circumvent the constitutional safeguards Miranda dictates." 14

If this interpretation is correct, then Miranda does not apply to tax investigations, because the taxpayer is legally free to leave an IRS interview and is not physically deprived of his freedom of action.

But the alternative reading of the phrase may bring tax cases within the scope of Miranda. Hewitt, in The Constitutional Rights of the Taxpayer in a Fraud Investigation, ${ }^{45}$ argues that the Court in Miranda was concerned not only with custody or deprivation of physical freedom of action, but also with the psychological impact of questioning on the individual's freedom of choice.

With the premise that the impact upon the person's mind is the most important element, defining "deprivation of free-

39 See Kamisar, supra note 18 , at 335-38.

40 See Hewitt, supra note 22, at 682-83.

41 See Kamisar, supra note 18, at 335-36.

42384 U.S. at 477 (emphasis added).

$43 \mathrm{Id}$. at 444.

44 Kamisar, supra note 18, at 336 (quoting Commonwealth v. Stites, $427 \mathrm{~Pa} .486$ 492, 235 A.2d 387, 390 (1967)) ; see United States v. Pierce, 397 F.2d 128, 130 (4th Cir. 1968); N. Sober, The New Confession Standards: Miranda v. Arizana 56-8 (1966).

4544 TAXEs 660 (1966). 
dom of action in any way" should subserve that need.

When the Revenue Agent and the Special Agent visit him, he is under the overwhelming apprehension that he has to cooperate, and supply them with the books and records which they seek. In his mind, he has no freedom to act in any other way. . . . The Court did not speak of a freedom of locomotion, or ability to move about without restraint. It spoke of "freedom of action," which must mean a freedom to act or belief in a freedom to act in some other manner than that which is compelled by the circumstances. ${ }^{46}$

If this second reading is correct, then a court faced with the question of Miranda warnings in a tax case must acknowledge that inherent psychological pressures in a tax investigation might require the warnings. Arguably, the physical freedom of action of the taxpayer reduces the psychological pressures on him to insignificance. ${ }^{47}$ But this approach requires nonetheless a balancing of the general psychological atmosphere of the interview against the extent to which physical freedom of action can mitigate any psychological pressure. Note that if a court were to accept this second reading of the "freedom of action" phrase, and allow that interrogations involving psychological pressure may be "custodial interrogations" within Miranda, it could decide once and for all that the psychological pressures inherent in a tax investigation are or are not great enough to require Miranda warnings in all tax cases.

Recent Supreme Court decisions tend to support the first interpretation of the phrase. The Court has held that "custodial interrogation" may occur outside of the police station, and in the absence of a formal arrest, if the suspect was not free to leave the scene. In Orozco v. Texas, ${ }^{48}$ the Court held that the warnings were required when a suspect was questioned in his bedroom. Emphasizing an officer's testimony that the defendant would not have been permitted to leave had he so desired, the Court ignored the question whether the suspect himself had felt free to leave. Thus an actual finding of inherent pressure

46 Id. 683.

47 On the other hand, some courts have recognized that if psychological freedom of action determines the question of compulsion, then not the suspect's legal freedom to leave, but his feeling of freedom, is important. See, e.g., People v. Arnold, $66 \mathrm{Cal}$. 2d 438, 448-49, 426 P.2d 515, 521, 58 Cal. Rptr. 115, 120 (1967) : "[C]ustody occurs if the suspect is physically deprived of his freedom of action in any significant way or is led to believe, as a reasonable person, that he is so deprived." See generally Kamisar, supra note 18 , at 360-82.

Hewitt implies that the taxpayer may feel compelled to cooperate with the IRS agent. Hewitt, supra note 22 , at 683 . Thus perhaps the reasonable man standard should apply. But the "subjective" test of Arnold actually rests on the apprehension of physical custody in the mind of the suspect. Because physical custody is not threatened in a tax investigation, and the reasonable taxpayer would not believe himself to be in custody, the standard is not applicable in tax cases.

48394 U.S. 324 (1969). 
on the suspect similar to that occurring during a police station interrogation was unnecessary. ${ }^{49}$

Similarly, in Mathis v. United States, ${ }^{50}$ the Court found that the interrogation of a taxpayer already in prison for an unrelated crime was a custodial interrogation requiring the Miranda warnings ${ }^{51}$ despite the absence of overt psychological compulsion and regardless of the defendant's familiarity with his surroundings at the time of the interview. ${ }^{\mathbf{5}}$

In no case, however, has the Court rejected the psychological "freedom of action" reading. Because Orozco and Mathis were in physical custody during the questioning, the Court was not forced to consider a psychological reading of Miranda.

But even if a court were to regard both possible interpretations of the "freedom of action" phrase, and find that Miranda does not control because the phrase refers to physical custody rather than to psychological pressure, it still has a duty to return to the fifth amendment and determine whether the pressures exerted in tax cases are inherently compelling. Miranda's concern with custody arose from its concern with compulsion. Upon finding that Miranda does not apply because of the absence of physical control, and thus of custody, in tax cases, a court might follow this line of reasoning: ${ }^{53}$ Purely as a matter of logic, to say that Miranda found compulsion inherent in custodial interrogations is not to say that an inherently compelling atmosphere may not exist in other circumstances. It is not enough merely to state that there is no compulsion in tax investigations simply because there is no custody. Just as Miranda demanded prophylactic warnings to combat the inherent pressure of custodial interrogations, so must a court require warnings upon a finding of inherent compulsion outside a custodial interrogation. A court in this situation would follow similar ground covered by a court finding the "freedom of action" phrase susceptible to a psychological reading; and, similarly, might properly determine that on balance the lack of physical custody negates any inherent compulsion in the tax interview. The difference is that the court allowing a psychological reading of the "freedom of action" phrase may on balance find that the Miranda decision itself controls, while the second court, having decided that Miranda refers only to custodial interrogations and thus does not apply, may decide that the philosophy behind Miranda-protection against inherently compelling situations-dictates that warnings be required.

The courts of appeals of most circuits have not followed this logic. Rather, they have found Miranda inapplicable by relying on two factual differences between a regular criminal investigation and a tax investi-

49 Id. at 330-31 (White, J., dissenting).

50391 U.S. 1 (1968).

51 Id. at $4-5$.

52 Id. at 7-8 (White, J., dissenting).

53 See generally Lipton, Constitutional Rights int Criminal Tax Investigations, 45 F.R.D. 323, 338 (1968); Hewitt, supra note 22, at 685. 
gation. In a line of cases beginning with Kohatsu v. United States, ${ }^{54}$ decided between the Escobedo and Miranda decisions, the Ninth Circuit has decided that, because in the usual criminal investigation the government seeks a culprit responsible for a known crime, while during a tax investigation the government seeks to determine if a crime has been committed, there is insufficient accusatory focus on the taxpayer to require the protections accorded regular criminal defendants.

No other circuit has fully adopted this distinction; ${ }^{55}$ and some courts, including the Dickerson court, have recognized the irrelevance of the difference. ${ }^{56}$ The purpose of both investigations is to discover evidence incriminating the suspect. In support of its criticism of the Ninth Circuit, the Dickerson court quoted language from Mathis: "[T] ax investigations frequently lead to criminal prosecutions." 57

Other circuits have refused to require the Miranda warnings in tax cases because they have found that the taxpayer was not in custody during the interview. ${ }^{58}$ Unfortunately, most of these courts have considered neither the possibility that custodial interrogation may mean deprivation of freedom in the psychological sense, nor whether tax investigations might be inherently compelling even in the absence of custody. These courts do no more than announce a conclusory syllogism: (1) Miranda warnings rested on the custodial nature of the interrogation; (2) taxpayers during the IRS investigations are not in formal custody; (3) therefore, Miranda does not require that warnings be given in these cases. But the error in refusing to look beyond the question of custody was discussed above." And because "custodial interrogation" also includes questioning when the suspect is deprived of his freedom of action in any significant way, the courts must first investigate the meaning of the phrase before concluding that Miranda does not apply.

The First and Fourth Circuits, while acknowledging that "custodial interrogation" may occur if there is a "deprivation of freedom of action," have nonetheless inadequately investigated the meaning

64351 F.2d 898 (9th Cir. 1965), cert. denied, 384 U.S. 1011 (1966) (one week after Miranda). The Ninth Circuit has consistently followed its Kohatsu opinion. See Selinger v. Bigler, 377 F.2d 542 (9th Cir.) (per curiam), cert. denvied, 389 U.S. 904 (1967); Rickey v. United States, 360 F.2d 32 (9th Cir.), cert. denied, 385 U.S. 835 (1966).

55 Several cases, however, cite Kohatsu for the proposition that Miranda does not apply, although they do not follow the Ninth Circuit's reasoning. See, e.g., Cohen v. United States, 405 F.2d 34 (8th Cir. 1968), cert. denied, 394 U.S. 943 (1969).

56 Even in normal criminal procedures the police do not know as a matter of fact that a crime has been committed; they have only a reasonable belief that a crime has been committed. See Note, The Constitutional Right to Connusel in Tax Investigations, 33 U. CHI. L. Rev. 134, 140 (1965).

57413 F.2d at 1115 (quoting Mathis v. United States, 391 U.S. 1, 4 (1968)).

58 See Agoranos v. United States, 409 F.2d 833, 835 (5th Cir. 1969) ; Hensley v. United States, 406 F.2d 481, 484 (10th Cir. 1968); Cohen v. United States, 405 F.2d 34, 40 (8th Cir. 1968), cert. denied, 394 U.S. 943 (1969); United States v. Maius, 378 F.2d 716, 718-19 (6th Cir.), cert. dentied, 389 U.S. 905 (1967).

59 See text accompanying notes $52-54$ supra. 
of the latter phrase. ${ }^{60}$ For example, in Spinney $v$. United States, ${ }^{61}$ the First Circuit stated :

Clearly . . . this defendant was not deprived of his freedom of action at all. He was not compelled to appear at the interview or answer questions. He did both voluntarily. . . . [W] here one is legally free, albeit at the risk of unpleasant consequences, to reject the government's invitation to appear and participate in an I.R.S. interview, the requirements enumerated in Miranda do not apply. ${ }^{\mathbf{6 2}}$

But apart from the absence of formal custody, the circumstances described by the Spinney court are dubiously relevant to the voluntariness of the evidence produced by the interview. Like the taxpayer, Miranda was neither legally required to answer questions asked him by the police nor to participate in their investigation of his crime. Thus, like the syllogism cases, Spinney actually rests on the absence of physical custody. The court did not recognize that the "freedom of action" phrase may have more than one meaning. And even if the court had decided that the phrase spoke only to custody (that is, the first reading), the court still should have decided whether, in the absence of custody, the atmosphere of the investigation was inherently compelling. Again, the shortcoming of these cases, and of the syllogism cases, is that they fail, first, to inquire into the meaning of "freedom of action" but simply assume it refers to formal in-custody situations; and second, to recognize that inherent compulsion is not contingent on custody. Thus, by finding an opportunity for inherent compulsion only where there is custody defined strictly in terms of physical control, the courts do not scrutinize each case under the harsh light of the fifth amendment prohibition established in Miranda. Only the Second Circuit has adequately recognized that Miranda, while on its facts a custody case, applied the warnings because of the inherently compelling atmosphere of custodial police interrogations. ${ }^{B 3}$ In United States $v$. Mackiereicz, ${ }^{\text {B4 }}$ the Second Circuit specifically addressed itself to the coercive atmosphere of the tax interview and decided that there was little compulsion because the taxpayer was in his own home and free to ask the agents to leave. ${ }^{65}$ While the distinction made in this case seems

60 See Spinney v. United States, 385 F.2d 908, 910 (1st Cir. 1967), cert. denied, 390 U.S. 921 (1968); United States v. Mancuso, 378 F.2d 612 , 619 (4th Cir.), modified, 387 F.2d 376 (4th Cir. 1967), cert. denied, 390 U.S. 955 (1968) ; Morgan v. United States, 377 F.2d 507, 508 (1st Cir. 1967).

61385 F.2d 908 (1st Cir. 1967), cert. denied, 390 U.S. 921 (1968).

$62 I d$. at 910 .

63 See United States v. Caiello, 420 F.2d 471 (2d Cir. 1969); United States v. Mackiewicz, 401 F.2d 219, 222-23 (2d Cir.), cert. denied, 393 U.S. 923 (1968); United States v. Squeri, 398 F.2d 785, 789 (2d Cir. 1968).

64401 F.2d 219 (2d Cir.), cert. denied, 393 U.S. 923 (1968).

65 This freedom may be illusory:

It begs the question to say that the taxpayer could terminate the interview at anytime by walking out the door. Only individuals who have not succumbed 
identical to those drawn in cases like Spinney, the Mackiewicz court recognized that custody per se is not determinative, and based its decision "not on a technical and unrealistic view of the custody requirement . . . but on the totality of the circumstances present at the interview." In In essence, the Second Circuit has taken the position that, while compulsion may be inherent in tax investigations, it is negated by the taxpayer's relative freedom of movement.

\section{The Dickerson Decision}

The Dickerson court followed neither the approach of those circuits relying primarily on the absence of custody, nor that of the Second Circuit. The opinion is confusing, but apparently the majority found that Miranda turned neither on the custody of the defendant nor on the inherent compulsion of the police station interrogation, but on the suspect's inability to intelligently waive his rights in an adversary confrontation without the benefit of a warning:

We understand the teaching of Miranda to be that one confronted with governmental authority in an adversary situation should be accorded the opportunity to make an intelligent decision as to the assertion or relinquishment of those constitutional rights designed to protect him under precisely such circumstances. ${ }^{67}$

The Dickerson court seems to have read Miranda as resting on alternative grounds of "focus" or "custody." 68 Thus, warnings are required not because of inherently compelling circumstances, but because the investigation had focused on the suspect. Reasoning supporting this argument may derive from the "obfuscating" 69 footnote four of the Miranda decision:

This [custodial interrogation as defined by the opinion ${ }^{70}$ ] is what we meant in Escobedo when we spoke of an investigation which has focused on an accused. ${ }^{71}$

to coercive pressure will follow that course. The individual who remains to answer questions may believe that he must do so and thus be deprived of his freedom of action in a significant way.

Note, Fifth Amendment Privilege in Criminal Tax Investigations: Miranda and the Omnibus Crime Act, 42 TEMrP. L.Q. 255, 265 (1969).

$66401 \mathrm{~F} .2 \mathrm{~d}$ at 222.

67413 F.2d at 1114 (emphasis added).

68 Numerous courts have similarly held in criminal cases, e.g., Windsor v. United States, 389 F.2d 530, 534 (5th Cir. 1968) ; Commonwealth v. Jefferson, $423 \mathrm{~Pa} .541$, 546, 226 A.2d 765, 768 (1967); cf. Allen v. United States, 390 F.2d 476 (D.C. Cir. 1968) (degree to which suspect is focused on is a major factor in determining when Miranda warnings are required).

69 Graham, What is "Custodial Interrogation?": California's Anticipatory Application of Miranda v. Arizona, 14 U.C.L.A.L. Rev. 59, 114 (1966).

T0 Text accompanying note 32 supra.

71384 U.S. at 444 n.4. 
Dickerson read the "in-custody" criterion as supplementing rather than displacing the Escobedo "focus" criterion. ${ }^{72}$ Perhaps the Dickerson court saw in Miranda a "wish to push the rule to cover situations where there is no custody, in the usual sense of the term, to restrict for example, deliberate use of informers to elicit evidence . . . ." 73 But recent Supreme Court decisions indicate that the Court was concerned not so much with "focus" as with the coercive atmosphere of in-custody interrogation. In Mathis v. United States, ${ }^{74}$ the Court followed the Miranda language and looked to aspects of custodial interrogation rather than to whether the government had focused on Mathis during a routine civil audit. ${ }^{75}$ In Orozco v. Texas, ${ }^{76}$ the Court conceivably could have based its decision on the fact that the officers had focused on the suspect when they began their questioning in his bedroom, but instead decided only on the grounds that the suspect was not free to leave. ${ }^{77}$ In $H o f f a v$. United States, ${ }^{78}$ the Court rejected defendant's contention that, although he was not under arrest or in custody at the time of his incriminating statements to an undercover agent, he was entitled to the Miranda warnings because the government had focused on him and had probable cause for an arrest. ${ }^{79}$

Lower courts have also criticized the "focus" alternative. United States $v$. Turzynnski ${ }^{80}$ in particular, the case most heavily relied upon by the Dickerson court for its reading of Miranda, ${ }^{81}$ has been explicitly rejected by other circuits. For example:

72 For an argument that the Miranda "in-custody" criterion displaces rather than supplements the Escobedo "focus" criterion see Kamisar, "Custodial Interrogation" Within the Meaning of Miranda, in CRIMINal LAW AND THE Constitution 335, 338-51 (1968).

73 Graham, supra note 69, at 115.

74391 U.S. 1 (1968). For a brief discussion of this case see text accompanying notes $50-52$ supra.

75 See 391 U.S. at 5.

76394 U.S. 324 (1969). For a brief discussion of this case see text accompanying notes $48-49$ supra.

$77 \mathrm{See} 394$ U.S. at 327.

78385 U.S. 293 (1966).

$79 \mathrm{Id}$. at 303-04.

80268 F. Supp. 847 (N.D. Ill. 1967). In holding that the Miranda warnings applied to the criminal tax investigation, the district court stated:

The inception of the adversary process was the core of the Court's concern in Escobedo and Miranda. While, as the Court pointed out, custody may have a coercive effect, it is also an easily recognizable point at which the adversary process can be said to have begun.

-..

While criminal tax investigations by their nature are almost always devoid of anything that smacks of custody, the administrative procedure of the Internal Revenue System offers at least one equally tangible point at which the adversary process can be said to have begun. . . . At this point the taxpayer is under suspicion of tax fraud, the investigatory power of the government is directed against him with the intent of developing evidence to convict him and his need to know his rights is quite as real and urgent as that of the suspect under custodial interrogation.

Id. at 853-54.

81 See 413 F.2d at 1115. 
[W]e reject the view, adopted by a few district courts in other circuits, that IRS agents must give the Miranda warnings, even though there is no custodial interrogation, if the investigation has reached the accusatory stage. United States v. Turzynski . . . . The Fifth Amendment privilege prohibits the government from compelling a person to incriminate himself. It was the compulsive aspect of custodial interrogation, and not the strength or extent of the government's suspicions at the time the questioning was conducted, which led the Court to impose the Miranda requirements . . . . We believe that the presence or absence of compelling pressures, rather than the stage to which the government's investigation has developed, determines whether the Miranda requirements apply to any particular instance of questioning. ${ }^{.2}$

The distinction is most apt. A careful reading of the fifth amendment leads to a rejection of the Turzynski-Dickerson argument. "It is compulsion to answer which offends against the fifth amendment provision that no person shall be compelled in any criminal case to be a witness against himself." 83 The Court in Escobedo spoke of "focus" because, as a sixth amendment case, it was concerned with the adequate and timely representation of the defendant in the adversary process. On the other hand, the Court in Miranda spoke repeatedly of "compulsion" out of a concern for the protection of a suspect's fifth amendment rights. The Escobedo requirement that an attorney be available was incorporated into Miranda not because of the focus of the governmental investigation but because the Court believed that the presence of an attorney mitigates the coercive atmosphere of a police interrogation and protects against police abuses. ${ }^{84}$

Furthermore, despite the Dickerson court's reliance on the analysis that

[i] ntelligent exercise or waiver of the Fifth Amendment privilege is the heart of the Court's concern in Miranda, ${ }^{85}$

the Miranda Court, in discussing intelligent exercise of the privilege, did not bar as unconstitutional "any statement given freely and voluntarily without any compelling influences," ${ }^{86}$ even though such statements be given without full knowledge of their consequences. For example, the Miranda Court stated that no warnings need be given to a man who enters a police station and voluntarily confesses-regardless of his knowledge of his right to remain silent. ${ }^{87}$ Finally, the Court in Hoff $a$ rejected the defendant's theory that, because his conversations

82 United States v. Squeri, 398 F.2d 785, 790 (2d Cir. 1968) (footnote omitted).

83413 F.2d at 1118 (Fairchild, J., dissenting).

84384 U.S. at 442, 465-66.

85413 F.2d at 1114 .

86384 U.S. at 478 . But see Andrews, supra note 20, at 1080 n.19.

87384 U.S. at 478. 
with an undercover agent occurred without intelligent waiver, evidence gathered therefrom should be excluded. The Court instead dealt only with the compulsion question:

[A]11 have agreed that a necessary element of compulsory self-incrimination is some kind of compulsion. . . . In the present case no claim has or could be made that the petitioner's incriminating statements were the product of any sort of coercion, legal or factual. The petitioner's conversations . . . were wholly voluntary. ${ }^{88}$

In conclusion, then, the Dickerson court failed to consider adequately recent decisions strongly reinforcing the primacy of Miranda's "in-custody" requirement over the Escobedo "focus" requirement.

\section{Compulston in Tax Cases}

Dickerson contradicts the Second Circuit's holding in Mackiewicz ${ }^{69}$ that the taxpayer's freedom of movement negates any inherent coercion present in the investigation. On balance, the Second Circuit appears to be correct.

The Dickerson court pointed out that psychological pressures on the taxpayer during the interview subtly but effectively induce him to cooperate with the IRS agents. ${ }^{90}$ Support for this position may be derived from a comparison of IRS agents' practices with those police practices condemned by Miranda. Both IRS special agents and police attempt to interrogate an individual in privacy so as to minimize psychological support from outside sources. ${ }^{91}$ Like the police, IRS agents personify the authority of the government; and the average taxpayer lacks both the knowledge of his constitutional rights and the toughness of fiber to refuse to answer their questions. ${ }^{92}$ Also, the Miranda Court regarded police manuals as a valuable source of information about the compulsive nature of police station interrogations; it should be noted that the IRS resists efforts to gain access to its investigative technique manuals and directives, and in one instance dismissed an action rather than comply with a court order to produce them..$^{93}$

88385 U.S. at 304. Although use of undercover agents is expressly at odds with the intelligent waiver reading of Miranda, their use has been upheld by the Supreme Court. See Lewis v. United States, 385 U.S. 206, 208-09 (1966); Osborn v. United States, 385 U.S. 323 (1966). But see Hoffa v. United States, 385 U.S. 293, 314-21 (Warren, C.J., dissenting).

89401 F.2d 219, 222-23 (2d Cir.), cert. denied, 393 U.S. 923 (1968). For a brief discussion of this case see text accompanying notes 63-66 sipra.

90 See 413 F.2d at 1115-16.

91 Hewitt, supra note 22, at 683 (1966). Interrogation in private was cited by the Supreme Court in Miranda as the principal psychological factor contributing to successful police interrogation. 384 U.S. at 449 (1966).

92 United States v. Maius, 378 F.2d 716, 719 (6th Cir.), cert. denied, 389 U.S. 905 (1967); see Andrews, supra note 20, at 1112-13; Lipton, supra note 53 at 336-37. 93 Lipton, supra note 53, at 337 n.61 (1968). 
Yet, despite evidence of some psychological coercion, clearly an interrogation by IRS agents in the familiar surroundings of a taxpayer's home or office is not as intimidating as the police station interrogation condemned by Miranda. In contrast to the picture painted in Miranda of the police third degree-relentless questioning for long hours, the omnipresence and omnipotence of the police surrounding the suspect-the criminal tax investigation usually spans a series of interviews perhaps continuing for as long as three years. ${ }^{94}$ The interviews themselves are often informal, akin to shop talks among businessmen. The taxpayer's freedom of movement, while not necessarily identical to the freedom to terminate the interview suggested by Mackiewicz, affords the taxpayer much respite between interviews. Statements given during these interviews are certainly less compelled than those elicited during police interrogations.

Thus, on the whole, the tax investigation does not possess the inherently compelling atmosphere of a custodial interrogation. While there may well be instances of true compulsion in tax investigations, the element of compulsion cannot be deemed so "inherent" in the circumstances as to indicate that the Miranda warnings and a shift in the burden of proof of voluntariness to the government are necessary to combat the infringement of fifth amendment rights. The voluntariness test is adequate to decide whether compulsion did exist in any particular case.

\section{An Alternative to the Dickerson Approach}

The IRS admitted in the Dickerson case that it had failed to give Miranda warnings or any other warnings of constitutional rights to Dickerson. ${ }^{95}$ In oral argument before the court, the government characterized the then existing IRS requirement-that its special agents give a modified version of the Miranda warnings at the first interview-as an act of grace. ${ }^{96}$ However, the IRS implementation of its own warning offers a more acceptable route to the same result sought by the Dickerson court. If, as this Comment has argued, Miranda does not apply, then the IRS is free to mold the warnings to better adapt to the problems raised in tax investigations. The IRS has placed the following requirements on the special agents:

At the initial meeting with a taxpayer, a Special Agent is now required to identify himself, describe his function, and advise the taxpayer that anything he says may be used against him. The Special Agent will also tell the taxpayer that he

94 See, e.g., Cohen v. United States, 405 F.2d 34 (8th Cir. 1968), cert. denied, 394 U.S. 937 (1969) (no arrest during investigation lasting 21/2 years) ; United States v. Turzynski, 268 F. Supp. 847 (N.D. I1l. 1967) (no arrest during approximately 3-year investigation).

$95413 \mathrm{~F} .2 \mathrm{~d}$ at 1112.

$96 \mathrm{Id}$. at $1117 \mathrm{n} .12$. 
cannot be compelled to incriminate himself by answering any questions or producing any documents, and that he has the right to seek the assistance of an attorney before responding. ${ }^{97}$

The warnings are not the full Miranda warnings that are given to the taxpayer after he is arrested. ${ }^{98}$ There is no provision for counsel for indigents; but the number of indigent taxpayers investigated by the IRS is "overwhelmingly small." "99 The warnings are nevertheless of concrete value to the taxpayer under investigation by special agents. The bare Miranda warnings and nothing else might mislead the taxpayer since they do not explain the purpose of the interrogation. ${ }^{100} \mathrm{By}$ requiring the special agent to state his purpose of investigating for possible criminal tax violations and to inform the taxpayer of his constitutional rights to remain silent and retain counsel, the IRS warning will immediately alert most taxpayers to the possible seriousness of their predicament.

Having instituted a warnings requirement, the IRS may not now disregard it. In United States $v$. Heffner, ${ }^{101}$ the taxpayer was not warned of the special agent's function nor advised that he could retain counsel during the interviews despite an IRS News Release ${ }^{102}$ (predecessor to the one now in effect ${ }^{103}$ ) stating that he would be so warned. The Fourth Circuit in Heffner based its decision on United States ex rel. Accardi v. Shaughnessy, ${ }^{104}$ in which the Supreme Court vacated a deportation order issued by the Board of Immigration because the procedure followed by the Board did not conform to its relevant regulations. The Court held that such deviation was a denial of due process. The Fourth Circuit, finding the same denial in the agent's deviation, held that admission at the trial of the special agent's testimony concerning the taxpayer's incriminating statements was reversible error calling for remand. ${ }^{105}$ The Heffner court explained:

An agency of the government must scrupulously observe rules, regulations, or procedures which it has established.

97 IRS News Release IR-949, Nov. 26, 1968, quoted in Cohen v. United States, 405 F.2d 34, 39 (8th Cir. 1968) (emphasis added). For the distinction between special agents and revenue agents see text accompanying notes 20-25 supra.

98 Text accompanying note 13 supra.

99 Telephone interview with Herbert S. Mednick (former special agent) in Philadelphia, Pa., Jan. 13, 1970.

100 See Comment, Constitutional Rights of the Taxpayer in a Tax Frand Investigation, 42 TuL. L. Rev. 862, 876 (1968).

101420 F.2d 809 (4th Cir. 1969).

102 IRS News Release No. 897, Oct. 3, 1967, reprinted in 7 CCH 1967 STAND. FED. TAX REP. $\$ 6832$.

103 Text accompanying note 98 supra.

104347 U.S. 260 (1954).

105 The Accardi doctrine does not terminate a case but requires a remand for new determinations consistent with established procedures irrespective of whether a new trial would produce the same result. See United States v. Heffner, 420 F.2d 809 (4th Cir. 1969). 
When it fails to do so, its action cannot stand and courts will strike it down. ${ }^{106}$

However, implementation of the IRS rule may pose some problems. In some instances, revenue agents, not subject to the prescriptions of the news release (which applies only to special agents), may unintentionally gather evidence sufficient for conviction before referral to the Intelligence Division. ${ }^{107}$ Yet to require IRS revenue agents to inform all taxpayers interviewed of the possibility of criminal prosecution might create needless anxiety and legal expense for the alarmed taxpayer. Because less than three-tenths of one per cent of all returns audited are carried beyond the routine audit and civil deficiency stage, ${ }^{108}$ a court is unlikely to find a compelling need for warnings. ${ }^{109}$

A more difficult problem may arise if the revenue agents either take it upon themselves or are encouraged by the IRS to expand their inquiries and seek incriminating evidence before referral to the Intelligence Division. ${ }^{110}$ Were this to happen, the revenue agent would be assuming the function of a special agent contrary to IRS regulations, ${ }^{111}$ and thus the principle of Heffner should prevail.

100 Id. at 811 ; see 413 F.2d at 1118 (Fairchild, J., dissenting).

107 See Cohen v. United States, 405 F.2d 34, 39 (8th Cir. 1968), cert. denied, 394 U.S. 943 (1969).

108 Duke, Prosecutions For Attempts To Evade Income Tax: A Discordant View of a Procedural Hybrid, 76 YALE L.J. 1, 34, 39 (1966).

109 See United States v. Mackiewicz, 401 F.2d 219 (2d Cir,), cert. denied, 393 U.S. 923 (1968).

110 Cohen v. United States, 405 F.2d 34, 39 (8th Cir. 1968), cert. denied, 394 U.S. 943 (1969).

111 In Mathis v. United States, 391 U.S. 1 (1968), the Court in finding an invalid interrogation looked not only to the agent's label-revenue or special-but also to his apparent purpose. The Court relied on the fact that, though the interview was superficially civil in nature, the last visit of the revenue agent took place only eight days before the full-fledged criminal investigation began. Id. at 4 . Furthermore, investigation of Mathis was prompted by a letter from local authorities to the IRS Intelligence Division which, for reasons not disclosed by the record, did not commence a criminal investigation but referred the matter to the IRS Audit Division. See Lipton, Supreme Cont's decision in Mathis likely to have very limited effect, 29 J. TAx. 32, 33 n.3 (1968). Thus, although the Court refused to draw a distinction between IRS revenue and special agents with regard to warning a taxpayer in prison, the Mathis record warrants the inference that the revenue agent was exceeding his civil function and gathering evidence for a criminal prosecution. Id. 32-33. 